January 2019

\title{
Library and Information Science Coauthorship Narrows the Divide Between Researcher and Practitioner
}

Stacy Andell

San Jose State University, gorillatopiary@yahoo.com

Follow this and additional works at: https://scholarworks.sjsu.edu/ischoolsrj

Part of the Information Literacy Commons, Scholarly Communication Commons, and the Scholarly Publishing Commons

Acknowledgements

\section{Recommended Citation}

Andell, S. (2019). Library and Information Science Coauthorship Narrows the Divide Between Researcher and Practitioner. School of Information Student Research Journal, 8(2). https://doi.org/10.31979/ 2575-2499.080203 Retrieved from https://scholarworks.sjsu.edu/ischoolsrj/vol8/iss2/3

This article is brought to you by the open access Journals at SJSU ScholarWorks. It has been accepted for inclusion in School of Information Student Research Journal by an authorized administrator of SJSU ScholarWorks. For more information, please contact scholarworks@sjsu.edu. 


\title{
Library and Information Science Coauthorship Narrows the Divide Between Researcher and Practitioner
}

\author{
Abstract \\ Evidence Summary Submission \\ Keywords \\ coauthorship, practicioner, researcher, academic \\ Acknowledgements
}




\title{
Library and Information Science Coauthorship Narrows the Divide Between Researcher and Practitioner
}

A Review of:

Chang, Y. W. (2016). Characteristics of articles coauthored by researchers and practitioners in library and information science journals. The Journal of Academic Librarianship, 42(5), 535-541. doi:10.1016/j.acalib.2016.06.021

\begin{abstract}
Objective - To determine whether researcher and practitioner collaboration has increased over time, as well as what sort of research such collaborators conduct.

Design - Bibliometric and content analyses

Setting - English LIS journals from 1995 to 2014

Subjects -2241 articles

Methods - Chang conducted a review of bibliographic records of research articles published in six journals between 1995 and 2014. The authors of these articles were divided into three categories: researchers, practitioners, and students. In terms of article research subjects, they were consolidated into 58 relevant subjects, which were further consolidated into 15 broad research subjects. At each step, articles which lacked the relevant information were excluded. A total of 2241 articles were examined.
\end{abstract}

Main Results - Chang tracked longitudinal changes for five article types based on authorship, with particular attention to articles coauthored by researchers and practitioners. Change notes that while single authorship has an overall downward trend, all forms of collaborative authorship have risen. The increase was not as pronounced for researcher and practitioner coauthorship, but the author concludes that this increase is evidence of a narrowing divide between researcher and practitioner. In terms of research subjects, Chang identified users and user services as the topic most likely to be coauthored by researchers and practitioners.

Conclusion - Based on the article analysis, Chang concludes that researcherpractitioner coauthorship is likely to increase in the future, though the trend is only slightly increasing in current research literature. For this reason, Chang indicates that further research and follow-up studies are necessary in order to determine if this trend continues or intensifies. In order to promote researcherpractitioner collaboration, Chang notes the research subjects most popular for these types of coauthorships, specifically technical services and user services. 
Future research could concentrate on expanding the research base beyond the initial six English LIS journals.

\section{Commentary}

Chang provides an overview of the coauthorship trends present in LIS scholarly literature, though she acknowledges that the scope of the study is limited and requires a broader analysis to draw more general conclusions. Chang builds on a strong foundation of research in this field, drawing on a series of similar bibliographic and content analyses to design the data collection procedure. The study is intended for both practicing and researching librarians or those interested in research collaboration.

The research questions are clearly defined, though the inclusion of both author and subject analyses can cause difficulty in determining how the two research questions are related to each other. There is not a clear relationship between the two sets of data aside from identifying the next steps in promoting researcher-practitioner partnerships. The statistical analysis of each category is thorough, carefully documented, and explained, as evidenced by Tables 3 and 4 (Chang, 2016). The section on data processing and analysis includes specific information about what was excluded and why. This section also offers clear definitions of terms as they are used within the framework of data collection. These definitions follow the model that Glynn (2006) suggests in her critical appraisal tool, a checklist for evidence-based library research.

Watson-Boone (2000) and Aytac and Slutsky (2014) provide a framework for evaluating library research. According to their guidelines (Watson-Boone, 2000; Aytac \& Slutsky, 2014), the main concern with this study is the way in which the conclusion is drawn and how it relates to the data. Analysis of the coauthor relationships in the data set points to only a slight increase in researcherpractitioner collaboration; however, Chang asserts that this modest increase confirms that the researcher-practitioner divide is narrowing. At the same time, the data points out stronger trends among the other types of collaboration that were not the focus of this study. While Chang does acknowledge that further research needs to be conducted, she also makes assumptions about how the trend will continue based on cited sources that indicate where other scholars feel it should continue, not necessarily reflecting the actuality of the data presented.

\section{References}

Aytac, S., \& Slutsky, B. (2014). Published library research, 2008 through 2012: Analyses and perspectives. Collaborative Librarianship, 6(4), 147-159. Retrieved from 
https://digitalcommons.du.edu/cgi/viewcontent.cgi?article=1085\&context $=$ collaborativelibrarianship

Glynn, L. (2006). A critical appraisal tool for library and information research. Library Hi Tech, 24(3), 387-399. doi:10.1108/07378830610692154

Watson-Boone, R. (2000). Academic librarians as practitioner-researchers. Journal of Academic Librarianship, 26(2), 85-93. doi:10.1016/S00991333(99)00144-5 